\title{
Superficial Communication Between Ulnar and Media Nerves in the Hand. An Anatomical Study
}

\author{
Comunicación Superficial entre los Nervios Ulnar \\ y Mediano de la Mano. Un Estudio Anatómico
}

Ivan Dario Quintero ${ }^{1,2}$; Luis Ernesto Ballesteros ${ }^{1}$; Pedro Luis Forero ${ }^{3,4}$

\begin{abstract}
QUINTERO, I. D.; BALLESTEROS, L. E.; FORERO, P. L. Superficial communication between ulnar and median nerves in the hand. An anatomical study. Int. J. Morphol., 39(6):1516-1520, 2021.

SUMMARY: The objective of this study was to characterize the communication between ulnar and the median nerve in the superficial palmar region from a sample of mestizo-raced population predominant in Latin America. The superficial palmar regions of 53 fresh cadaveric specimens were evaluated, whom of which underwent necropsy procedure at the Institute of Legal Medicine. Dissection was performed by planes until visualizing the presence of the Communicating Branch (CB) between the digital branches of the ulnar nerve (UN) and the median nerve (MN). Qualitative and morphometric evaluation of the CB was carried out.A CB were observed in 82/ $106(77.4 \%)$ of the cadaveric specimens studied, of which, 38/53 (71.7\%) were bilateral, $15 / 53(28.3 \%)$ unilateral; this being a statistically significant difference $(\mathrm{p}<0.002)$. Oblique trajectory of the CB between the fourth and third common digital nerve was observed in $70(85.4 \%)$ specimens, while the CB with transverse trajectory was found in $7(8.5 \%)$ regions and in a plexiform form in 5 $(6.1 \%)$ cases. The length of the $\mathrm{CB}$ was $20.2 \pm 5.1 \mathrm{~mm}$ and the distances from the upper edge of the flexor retinaculum to the proximal and distal points of the $\mathrm{CB}$ were $25 \pm 6 \mathrm{~mm}$ and $37.4 \pm 8.3 \mathrm{~mm}$ respectively. The anatomical characteristics of the $\mathrm{CB}$ patterns, as well as the morphometric $\mathrm{CB}$ findings and their points of reference from the carpal flexor retinaculum, make it possible to delimit a safe area of surgical access in the first-fifth proximal of the palmar region, during the surgical approach of carpal tunnel syndrome.
\end{abstract}

KEY WORDS Tunnel carpal release; Median nerve; Ulnar nerve.

\section{INTRODUCTION}

The communication between the ulnar and median nerves at the superficial palmar level (CUMSP) is also called Berrettini communication. This communicating branch (CB) occurs between the fourth common digital nerve derived from the ulnar nerve (UN) and the third common digital nerve derived from the median nerve (NM). The existence of this anatomical variant may slightly modify the sensory distribution of the third interdigital space. A high incidence of this $\mathrm{CB}$ is reported by the majority of authors in a range of 80-96.4 \% (Kimura et al., 1983; Meals \& Shaner, 1983; Ferrari \& Gilbert, 1991; Kolic et al., 1997; Stancic et al., 1999; Don Griot et al., 2000; Olave et al., 2001; Vieria et al., 2002; Loukas et al., 2007).

The CB of oblique trajectory, originating proximal or distally to the inferior margin of the flexor retinaculum of the carpus is the most usual presentation in a range of 70-80 $\%$ (Meals \& Shaner; Ferrari \& Gilbert; Kolic et al.; Bas \&
Kleinert, 1999; Tagil et al., 2007). The transverse trajectory is reported with an intermediate frequency, in a range of 7$22 \%$ (Ferrari \& Gilbert; Kolic et al.; Bas \& Kleinert; Don Griot et al.; Tagil et al.). Although the CB is thin and could eventually be confused with a band of connective tissue. Previous reports have not complemented the macroscopic evaluation of the corresponding histological studies.

Of the multiple biometric CB evaluations, it is worth mentioning their length, reported to range from $16-9.21 \mathrm{~mm}$ (Don Griot et al.; Loukas et al.) similarly, the distance of their points of origin from the UN and their connection with the third common digital nerve, in relation to the upper edge of the flexor retinaculum, has been reported in previous studies (Don Griot et al.; Olave et al.; Vieria et al.). The CUMSP acquires great importance during incisional or endoscopic surgical procedures of the palm, due to the risk of accidental lesions (Don Griot et al.; Loukas et al.; Tagil et al.).

\footnotetext{
${ }^{1}$ Division of Human Anatomy, Department of Basic Sciences, School of Medicine, Industrial University of Santander. Bucaramanga, Colombia

${ }^{2}$ Division of Orthopedic Surgery, Department of Surgery, School of Medicine, Industrial University of Santander. Bucaramanga, Colombia.

${ }^{3}$ Division of Legal Medicine, Department of Pathology, School of Medicine, Industrial University of Santander. Bucaramanga, Colombia.

${ }^{4}$ National Institute of Legal Medicine and Forensic Sciences, Bucaramanga, Colombia.
} 
The determination of the CUMSP, has been described in other population groups in a detailed manner. Given the scarce information on this CB in the Latin American mestizo population, the purpose of the present study was to characterize the communication between ulnar and the median nerve in the superficial palmar region

\section{MATERIAL AND METHOD}

This non-probabilistic and descriptive cross-sectional study determined the frequency and morphological characteristics of the $\mathrm{CB}$ in the superficial palmar regions of 53 fresh cadaveric specimens, which underwent necropsy at the Institute of Legal Medicine of Bucaramanga (Colombia). The sample met the following inclusion criteria: male subjects, adults, of the mestizo racial group, without evidence of direct trauma or hand pathology.

In the superficial palmar region, its length was determined from the bistyloid line to the proximal digital fold of the third finger.

With the hand in supination, an incision was made from the distal crease of the wrist to the proximal crease of the ring finger. A meticulous dissection was performed on each of the palmar region layers and subsequently, the fascious cutaneous flaps were harvested laterally and medially. The palmar aponeurosis and the superficial palmar arch were resected and released, allowing the visualization of the digital common nerves of the UN and $\mathrm{MN}$ and also the presence or absence of CB between these nerves.

For the determination of the CB trajectory, the Ferrari \& Gilbert classification was adopted and modified, joining in a group the oblique communicating branches. Subsequently, the length of the CB and the distances of its proximal and distal points were measured in relation to the proximal and distal edges of the carpal flexor retinaculum.

For each of the morphometric evaluations, a digital caliper (Mitotuyo ${ }^{\circledR}$ ) was used and the findings were photographed with a Cannon T2I camera. After recording the macroscopic findings, the CBs was subjected to fixation with $10 \%$ formaldehyde, stained with hematoxylin-eosin and evaluated under an optical microscope in order to either confirm or rule out the presence of a nervous microstructure.

The obtained findings were registered in Excel and the statistical analysis were performed in STATA 9.0. In the analysis of the data, the nominal variables were described with their proportions, the continuous ones with their averages and standard deviation. The statistical tests of chi $\left(\mathrm{X}^{2}\right)$ square were carried out accepting an alpha error of up to $5 \%$.

\section{RESULTS}

A CB was observed in $82 / 106(77.4 \%)$ of the cadaveric specimens studied, of which, 28/53 (71.7\%) were bilateral, $15 / 53(28.3 \%)$ unilateral, this being a statistically significant difference $(\mathrm{p}<0.002)$. In addition, 82 communications were found in the evaluated palmar regions, 45 right and 37 left, this not being significant statistical difference $(\mathrm{p}=0.71)$.

Group I (Fig. 1) with a CB of oblique trajectory between the fourth and third common digital nerve was observed in 70/82 (85.4\%) palmar regions, showing a significant difference of this finding over the other groups $(p<0.01)$. Group II, with a transverse path between the fourth

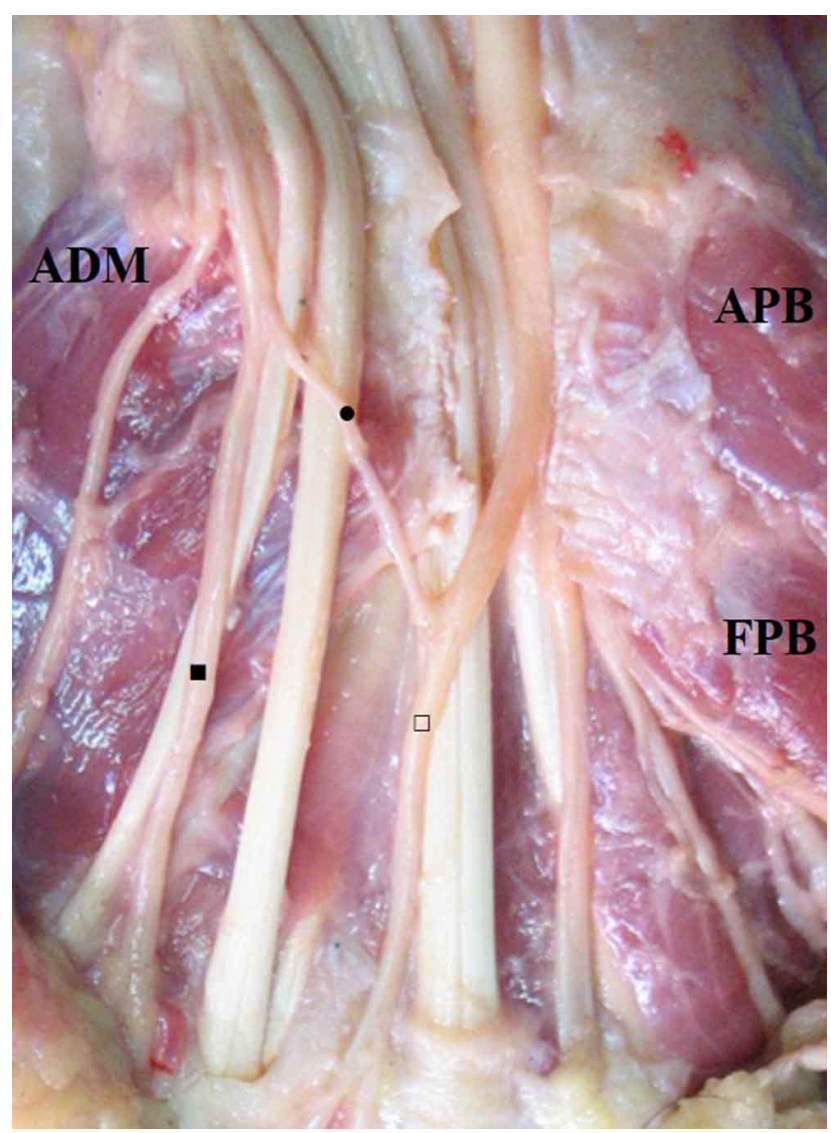

Fig. 1. Left palmar region, superficial plane.; FPB. Flexor Pollicis Brevis; APB. Abductor pollicis brevis muscle; ADM. Abductor digiti minimi muscle; ( $\mathbf{a}$ IV Common palmar digital nerve; ( $\square$ ) III Common palmar digital nerve; (•) Communicating branch with oblique trajectory ulnar-median. 
and third common digital nerve (Fig. 2) was found in 7/82 $(8.5 \%)$ regions and on group III, with branches of plexiform shape (Fig. 3) was observed in 5 (6.1\%) cases.

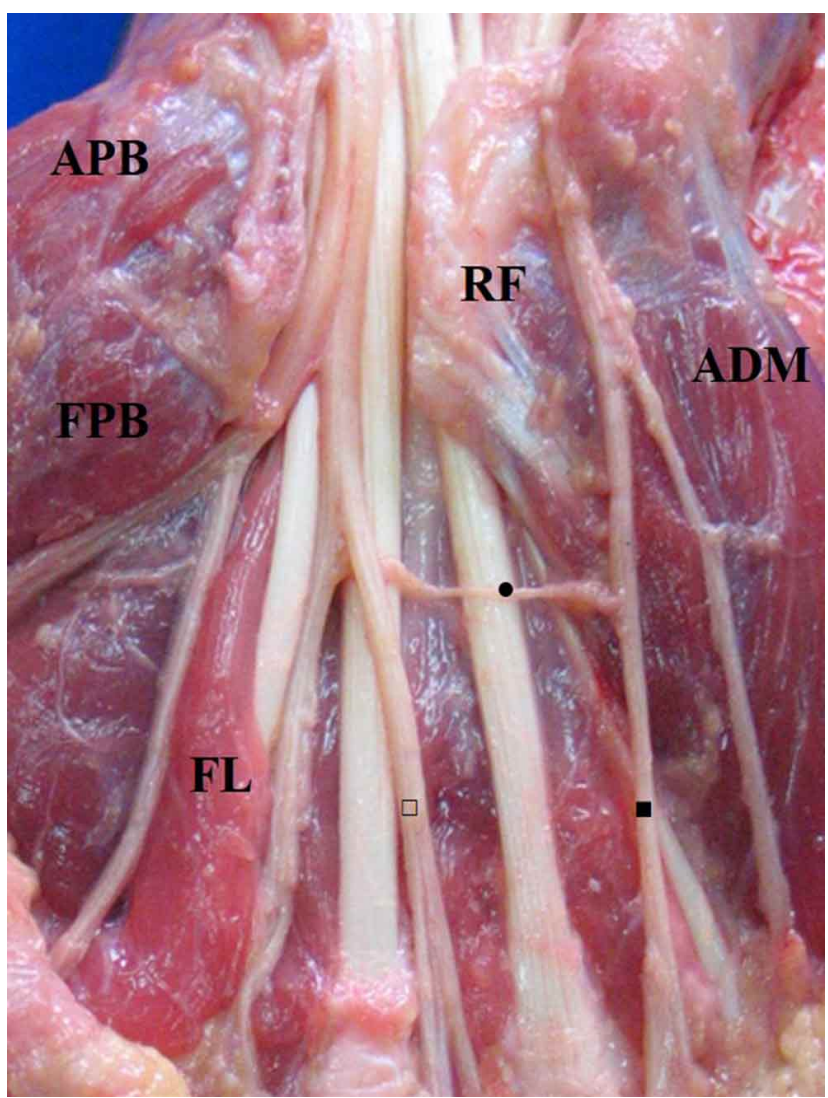

Fig. 2. Right palmar region, superficial plane. APB. Abductor pollicis brevis muscle; FPB. Flexor Pollicis Brevis; ADP. Adductor pollicis muscle; FR. Flexor retinaculum; FL. First lumbrical; ADM. Abductor digiti minimi muscle; (a) IV Common palmar digital nerve; ( $\square$ ) III Common palmar digital nerve; (•) Communicating branch with transverse trajectory.

The length of the CB was $20.2 \pm 5.1 \mathrm{~mm}$, corresponding to the right side $21.1 \pm 5.7 \mathrm{~mm}$, and to the contralateral side $19.4 \pm 4.4 \mathrm{~mm}$, without this difference being statistically significant $(P=0.9)$. The distances from the proximal edge of the flexor retinaculum to the proximal and distal points of the $\mathrm{CB}$ were $25 \pm 6 \mathrm{~mm}$ and $37.4 \pm 8.3$ $\mathrm{mm}$ respectively. The length of the palm of the hand, measured from the bistyloid line of the wrist distal crease to the proximal digital fold of the third finger was $101 \pm 8.8$ $\mathrm{mm}$; and when dividing the palm into five horizontal segments of $20.2 \mathrm{~mm}$, the CB located in the second fifth proximal of the palmar region was observed in all cases. Likewise, in the histological evaluation of the samples obtained from the $\mathrm{CB}$, it was observed that $100 \%$ of the cases presented a microscopic structure of the peripheral nerve, identifying the epineural connective tissue and the fascicles surrounded by the perineurium (Fig. 4).

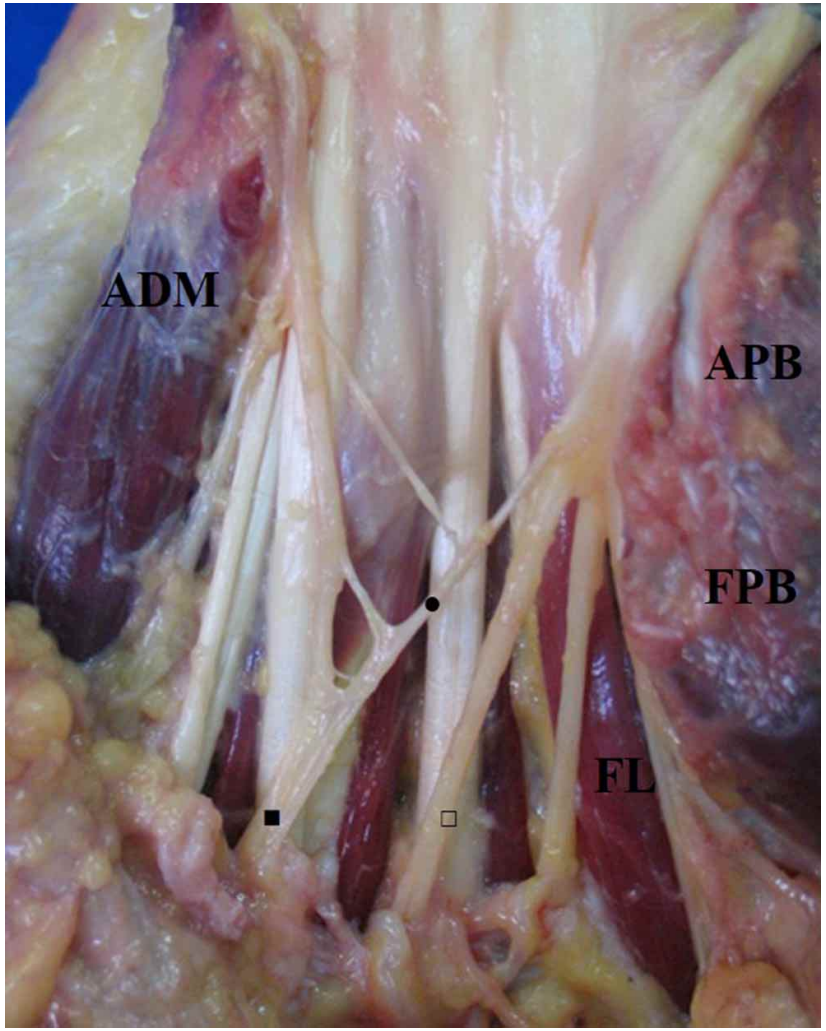

Fig. 3. Left palmar region, superficial plane.; APB. Abductor pollicis brevis muscle; FPB. Flexor Policis Brevis; ADM. Abductor digiti minimi muscle; FL. First lumbrical; (ם) IV Common palmar digital nerve; () III Common palmar digital nerve; (•) Communicating branches.

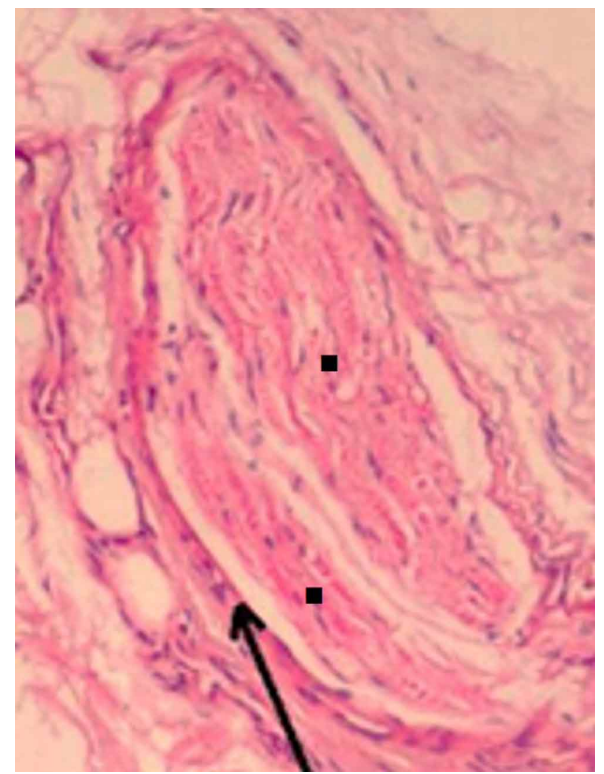

Fig. 4. Microphotography of an ulnar median communication in the superficial palmar region. the arrow indicates the epineurum. (ロ)Nerve fascicles of the communicating branch. 10X magnification, hematoxylin-eosin stain. 


\section{DISCUSSION}

The frequency of $\mathrm{CB}$ is reported by the majority of authors in a range of 80-90 \% (Meals \& Shaner; Ferrari \& Gilbert; Kimura et al.; Kolic et al.; Stancic et al.; Vieria et al.; Loukas et al.) even some studies (Don Griot et al.; Olave $e t a l$.) report incidents up to $96.4 \%$. The frequency of $\mathrm{CB}$ observed in our series $(77.4 \%)$ is in an intermediate range in relation to the majority of reports. Although, there are other reports that show a low range of 29.5-74\% (Biafora \& Gonzalez, 2007; Tagil et al.; Unver Dogan et al., 2010; Yang et al., 2016; Kara et al., 2018). The wide variability in the presentation of this $\mathrm{CB}$ can be explained by differences in the size of the samples, methodologies used, and the various phenotypic biological expressions of the population groups evaluated.

In the dissection of the palm and identification of the $\mathrm{CB}$, in some samples, it is possible to make the mistake of confusing a thin connective tissue band, biasing the results with figures higher than the real ones; therefore, histological confirmation is proposed in these cases, as was done in this study.

Regarding the classification of the CUMSP, group I, with CB of oblique trajectory between the fourth and third common digital nerve was the most frequently observed in our study $(85.4 \%)$ figure that is slightly higher than those indicated in previous works (Meals \& Shaner; Ferrari \& Gilbert; Kolic et al.; Don Griot et al.; Tagil et al.). Don Griot et al. (2000) report a frequency of $88 \%$ for this anatomical expression. For group II, with CR of transverse trajectory, the frequency observed in our series was lower $(8.5 \%)$ than in most literature reports (Ferrari \& Gilbert; Kolic et al.; Don Griot et al.; Tagil et al.), while group III, with branches of a plexiform form, our report of $6.1 \%$ concurs with the studies that describe it with an incidence of 4-10\% (Ferrari \& Gilbert; Don Griot et al.; Tagil et al.). In this study, we adopted a classification of the CUMSP (Ferrari \& Gilbert) that, in addition to providing simple and accurate information, enriches the anatomical concept and constitutes a great contribution, allowing adequate approaches in the traditional and minimally invasive surgery of the palm of the hand.

The length of the CUMSP described by Don Griot et al. and Loukas et al. is similar to that found in our series (20.2 mm). Likewise, other morphometric aspects, such as the distances of the proximal and distal points of the CB to the upper edge of the flexor retinaculum ( 25 and $37.4 \mathrm{~mm}$ respectively) are in accordance with previous studies that indicate for these measurements, ranges of $24-30 \mathrm{~mm}$ and
40-43 mm respectively (Don Griot et al.; Olave et al.; Vieria et al.).

Tunnel carpal release is a common surgical procedure and better results have been shown when this is done by surgeons undergoing additional handtraining fellowship (Mathen et al., 2018). Surgical treatment can be performed through open tunnel carpal release or endoscopic tunnel carpal release (Evers et al., 2018). Neurological complications during tunnel carpal release can compromise the UN, NM and digital nerves (Verdecchia et al., 2018). However, it is likely that CB can be compromised during tunnel carpal release procedures. Moreover, during clinical assessment, these $\mathrm{CB}$ lesions can be interpreted as digital nerve lesions given the similarity in sensitivity of the third interdigital volar space, thus be constituted as cause for legal medical litigation and clinical manifestations (persistent pain and numbness in addition to regional sympathetic dystrophy). All of these lesions can be similar to those described in this region (Benson et al., 2006).

The presence of CUMSP, observed at the level of the second proximal fifth of the palmar region, makes it possible for this area to be vulnerable to complications associated with sharp cutting injuries or surgical procedures that can generate neuromas in these $\mathrm{CB}$ and also making the diagnosis difficult in hand clinical assessment of the hand. The anatomical characteristics in the patterns of CUMSP as well as the morphometric findings of the CB and its points of reference from the flexor retinaculum, allows delimitation of a safe surgical access area in the first fifth proximal of the palmar region, during the surgical approach of carpal tunnel syndrome.

\section{ACKWNOWLEDGMENTS}

We would like to recognize the National Institute of Forensic Medicine, Northeastern Colombian region, for supplying the anatomical pieces used in this study.

QUINTERO, I. D.; BALLESTEROS, L. E.; FORERO, P. L. Comunicación superficial entre los nervios ulnar y mediano de la mano. Un estudio anatómico. Int. J. Morphol., 39(6):1516-1520, 2021.

RESUMEN: El objetivo de este estudio fue caracterizar la comunicación entre los nervios ulnar y mediano en la región palmar superficial a partir de una muestra de población de raza mestiza predominante en América Latina. Se evaluaron las regiones palmares superficiales de 53 especímenes cadavéricos frescos, los cuales fueron sometidos procedimiento de necropsia en el Ins- 
tituto de Medicina Legal. La disección se realizó por planos hasta visualizar la presencia del ramo comunicante (RC) entre los ramos digitales palmares del nervio ulnar (NU) y del nervio mediano (NM). Se realizó evaluación cualitativa y morfométrica del RC, observándose RC en 82/106 (77,4 \%) de los especímenes cadavéricos estudiados, de los cuales $38 / 53(71,7 \%)$ eran bilaterales, 15/53 (28,3\%) unilaterales; siendo esta una diferencia estadísticamente significativa $(\mathrm{p}<0,002)$. Se observó trayectoria oblicua del RC entre el cuarto y tercer nervio digital palmar común en 70 muestras $(85,4 \%)$, mientras que el RC con trayectoria transversal se encontró en 7 casos $(8,5 \%)$ y en forma plexiforme en 5 casos $(6,1 \%)$. La longitud del RC fue de 20,2 $\pm 5,1 \mathrm{~mm}$ y las distancias desde el margen superior del retináculo flexor hasta los puntos proximal y distal del RC fueron de $25 \pm 6 \mathrm{~mm}$ y $37,4 \pm 8,3$ $\mathrm{mm}$, respectivamente. Así, los hallazgos morfométricos del RC y sus puntos de referencia, desde el retináculo flexor, permiten delimitar una zona segura de acceso quirúrgico en el primer-quinto proximal de la región palmar, durante el abordaje quirúrgico del síndrome del túnel carpiano.

PALABRAS CLAVE: Liberación del túnel carpiano; Nervio mediano; Nervio ulnar.

\section{REFERENCES}

Bas, H. \& Kleinert, J. M. Anatomic variations in sensory innervation of the hand and digits. J. Hand Surg. Am., 24(6):1171-84, 1999.

Benson, L. S.; Bare, A. A.; Nagle, D. J.; Harder, V. S.; Williams, C. S. \& Visotsky, J. L. Complications of endoscopic and open carpal tunnel release. Arthroscopy, 22(9):919-24, 924.e1-2, 2006.

Biafora, S. J. \& Gonzalez, M. H. Sensory communication of the median and ulnar nerves in the palm. J. Surg. Orthop. Adv., 16(4):192-5, 2007.

Don Griot, J. P.; Zuidam, J. M.; van Kooten, E. O.; Prosé, L. P. \& Hage, J. J. Anatomic study of the ramus comunicans between the ulnar and median nerves. J. Hand Surg. Am., 25(5):948-54, 2000.

Evers, S.; Jansen, M. C.; Slijper, H.; de Haas, K. P.; Smit, X.; Porsius, J. T.; Hovius, S. E. R.; Amadio, P. C. \& Selles, R. W. Hand surgeons performing more open carpal tunnel releases do not show better patient outcomes. Plast. Reconstr. Surg., 141(6):1439-46, 2018.

Ferrari, G. P. \& Gilbert, A. The superficial anastomosis on the palm of the hand between the ulnar and median nerves. J. Hand Surg. Br., 16(5):511-4, 1991.

Kara, A. B.; Elvan, Ö.; Öztürk, N. C. \& Öztürk, A. H. Communications of the median nerve in foetuses. Folia Morphol. (Warsz), 77(3):4416, 2018.

Kimura, I.; Ayyar, D. R. \& Lippmann, S. M. Electrophysiological verification of the ulnar to median nerve communications in the hand and forearm. Tohoku J. Exp. Med., 141(3):269-74, 1983.

Kolic, Z.; Micovic, V.; Zamolo, G.; Golubovic, V.; Uravic, M. \& Stancic, M. F. The anatomy of the Berrettini branch: implications for endoscopic carpal tunnel release. J. Neurosurg., 1997. DOI: https:// www.doi.org/10.3171/foc.1997.3.1.10

Loukas, M.; Louis Jr., R. G.; Stewart, L.; Hallner, B.; DeLuca, T.; Morgan, W.; Shah, R. \& Mlejnek, J. The surgical anatomy of ulnar and median nerve communications in the palmar surface of the hand. $J$. Neurosurg., 106(5):887-93, 2007.

Mathen, S. J.; Nosrati, N. N. \& Merrell, G. A. Decreased rate of complications in carpal tunnel release with hand fellowship training. J. Hand Microsurg., 10(1):26-8, 2018.
Meals, R. A. \& Shaner, M. Variations in digital sensory patterns: a study of the ulnar nerve-median nerve palmar communicating branch. $J$. Hand Surg. Am., 8(4):411-4, 1983.

Olave, E.; del Sol, M.; Gabrielli, C.; Mandiola, E. \& Rodrigues, C. F. Biometric study of the relationships between palmar neurovascular structures, the flexor retinaculum and the distal wrist crease. J. Anat., 198(Pt. 6):737-41, 2001.

Stancic, M. F.; Micovic, V. \& Potocnjak, M. The anatomy of the Berrettini branch: implications for carpal tunnel release. J. Neurosurg., 91(6):1027-30, 1999.

Tagil, S. M.; Bozkurt, M. C.; Ozçakar, L.; Ersoy, M.; Tekdemir, I. \& Elhan, A. Superficial palmar communications between the ulnar and median nerves in Turkish cadavers. Clin. Anat., 20(7):795-8, 2007.

Unver Dogan, N.; Uysal, I. I.; Karabulut, A. K.; Seker, M. \& Ziylan, T. Communications between the palmar digital branches of the median and ulnar nerves: A study in human fetuses and a review of the literature. Clin. Anat., 23(2):234-41, 2010.

Verdecchia, N.; Johnson, J.; Baratz, M. \& Orebaugh, S. Neurologic complications in common wrist and hand surgical procedures. Orthop. Rev. (Pavia), 10(1):7355, 2018.

Vieria, L. A.; Caetano, M. B.; Yoshi, P. M.; Sabongi Netp. J. J. \& Caetano, E. B. Estudo anatômico da anastomose entre os ramos sensitivos dos nervos ulnar e mediano na palma da mão. Rev. Bras. Ortop., 37(8):336-40, 2002.

Yang, H.; Gil, Y.; Kim, S.; Bang, J.; Choi, H. \& Lee, H. Y. From the brachial plexus to the hand, multiple connections between the median and ulnar nerves may serve as bypass routes for nerve fibres. $J$. Hand Surg. Eur. Vol., 41(6):648-56, 2016.

Corresponding author:

Ivan Dario Quintero. MD.

Division of Human Anatomy

Department of Basic Sciences

School of Medicine

Industrial University of Santander

Cra $32 \mathrm{~N}^{\circ} 29-31$

Bucaramanga

COLOMBIA

E-mail: ivanquinterop@gmail.com

Received: 20-07-2021

Accepted: $31-08-2021$ 